\title{
PERKAWINAN LANSIA DI KECAMATAN SOCAH KABUPATEN BANGKALAN PERSPEKTIF MAQASID AL-SHARI'AH
}

\author{
Roisul Umam Hamzah \\ Jl. Maritim, Dsn. Tedunan, Desa Socah, Kec. Socah.Bangkalan. \\ Email: roizwolez@gmail.com
}

\begin{abstract}
This is a field research that analyzes the marriage suitability of elderly people in Socab, Bangkalan under the theory of maqasid shari'ah. The elderly marriage is officially conducted at KUA (Religious Affairs Office) of Socah for different reasons, namely: on the basis of coercion to the bride so that the family relationship does not break up, resulting in reluctance, on the basis of family compassion and encouragement. It is because the bride is an old maid and is his own niece on the basis of mutual love, avoid immorality and seek, peace of life in old age. All couples can fulfill both material and non-material obligations, although not as perfect as a young couple. Some husbands do not want to have children for fear of not being able to support even though in this case the wife really wants it. Thus, the marriage of the elderly in Socah is sometimes appropriate and not in accordance with the maqasid shari'ah. The suitability in question is in terms of hifz al-din (protecting religion) and hifz al-mal (protecting wealth), while its inadequacies are in terms of hifz, al-nasl (protecting offspring), because of their desires to have offspring and in terms of hifz al-nafs (protecting soul), and hifz al-'aql (protecting ratio), because of differences in descent have the negative effect on family disharmony that can interfere with the soul and mind. In this case, an intense dialogue and approach must be made to the couple to be more open and understand each other.
\end{abstract}

Keywords: Elderly marriage, maqasid shari'ah

\begin{abstract}
Abstrak: Artikel ini merupakan penelitian lapangan yang menganalisis kesesuaian perkawinan lansia di Kecamatan Socah Kabupaten Bangkalan dengan teori maqasid shari'ah. Perkawinan lansia tersebut dilakukan secara resmi di KUA Socah dengan alasan yang berbeda, yaitu: atas dasar pemaksaan kepada mempelai wanita agar tali silaturrahim antar keluarga tidak putus sehingga menimbulkan ketidakrelaan, atas dasar belas kasihan dan dorongan keluarga karena mempelai wanita adalah perawan tua dan merupakan keponakan sendiri, dan atas dasar saling suka, menghindari maksiat dan mencari ketenangan hidup di masa tua. Semua pasangan dapat memenuhi kewajiban baik materi maupun non materi, meskipun tidak sesempurna pasangan muda dan beberapa suami tidak menginginkan anak karena takut tidak mampu menafkai meskipun dalam hal ini istri sangat menginginkannya. Dengan demikian perkawinan lansia di Kecamatan Socah adakalanya sesuai dan tidak sesuai dengan maqasid shari'ah. Adapun kesesuaian yang dimaksud adalah dari segi hifz al-din dan hifz al-mal,
\end{abstract}

AL-HUKAMA

The Indonesian Journal of Islamic Family Law Volume 08, Nomor 02, Desember 2018; ISSN:2089-7480 
sedangkan ketidaksuainnya adalah dari segi bifz al-nasl karena tidakinginnya memiliki keturunan dan dari segi bifz, al-nafs dan bifz al-'aql, karena adanya perbedaan pendapat terkait keturunan bardampak pada ketidak harmonisan keluarga yang dapat mengganggu jiwa dan akal. Dalam hal ini, harus diadakan dialog dan pendekatan yang intens kepada pasangan agar dapat lebih terbuka dan saling memahami satu sama lain.

Kata Kunci: perkawinan lansia, maqasid al-shari'ah

\section{Pendahuluan}

Manusia adalah makhluk yang lebih dimuliakan dan diutamakan oleh Allah Swt. dibandingkan dengan makhluk-makhluk lainnya. Allah tidak membiarkan manusia berbuat semaunya, seperti binatang yang tidak memiliki akal. Dalam hal ini, Allah telah menetapkan berbagai aturan bagi manusia dan tidaklah boleh dilanggar, manusia boleh berbuat apa saja asalkan perbuatan tersebut tidak dilarang oleh agama. Allah memberikan batasan dengan peraturan-Nya, yaitu dengan syari'at yang terdapat dalam kitab-Nya, termasuk dengan hukum-hukum perkawinan dan hukum-hukum lainnya yang saling terkait dengan perkawinan, seperti kewajiban suami terhadap istri salah satunya adalah saling menjaga baik antara lahiriah dan batiniahnya.

Islam mengajarkan bahwa perkawinan tidaklah hanya sebagai ikatan lahiriah saja, seperti jual beli, sewa menyewa dan lain-lain, melainkan merupakan suatu perjanjian suci, di mana kedua belah pihak berikrar menjadi suami isteri atau menjadi pasangan hidup baik dalam kesusahan atau kesenangan dengan mengunakan nama Allahı, Sebagaimana yang terdapat dalam firman Allah QS. Ad Dariyat (49) yang artinya:

Dan kami ciptakan segala sesuatu berpasang-pasangan supaya kamu mendapat pengajaran. 2

Berdasarkan ayat Alquran di atas, sudah jelas bahwa Islam menganjurkan perkawinan yang baik agar terwujud keluarga yang baik pula yang mampu mengatur kehidupan mereka di bumi ini dan dapat menikmati serta memanfaatkan segala yang disediakan oleh

1Badan Penasehat Pembinaan dan Pelaksanaan Perkawinan, Tuntunan Praktis Rumah Tangga Bahagia, (Sidoarjo: BP4, 2012), 8.

2Tim Disbintalad, Al-Qur'an dan Terjemahnya, (Jakarta: PT Sari Agung,1995),1049. 
Allah. Dengan adanya ikatan pernikahan, akan menimbulkan suatu tanggung jawab serta kewajiban bagi suami kepada istri.

Mangenai pernikahan telah diatur dalam pasal 1 Undangundang Nomor 1 Tahun 1974 tentang Perkawinan yang berbunyi: "Perkawinan adalah ikatan lahir dan batin antara seseorang laki- laki dengan seorang perempuan, sebagai suami istri dengan tujuan membentuk keluarga (rumah tangga) yang bahagia dan kekal berdasarkan Ketuhanan Yang Maha Esa".3

Perbedaan antara laki-laki dan perempuan sangat terlihat, yaitu laki-laki lebih menonjol dengan fisiknya yang terlihat lebih kuat, sedangkan tidak dengan perempuan, sehingga hak yang seimbang wajib disesuaikan dengan adanya perbedaan antara laki-laki dan perempuan, mempersamakan berarti menimbulkan ketidakseimbangan. Dengan demikian, akan menimbulkan tanggung jawab yang berbeda pula. Laki- laki sebagai pelindung dan perempuan yang dilindungi, laki-laki adalah sosok imam yang berperan sangat penting bagi terbentuknya sebuah keluarga yang sesuai dengan defenisi dari syariat Islam.

Tampak adanya suatu perbedaan tanggung jawab antara suami dan istri, Allah Swt. telah menakdirkan adanya suatu perbedaan antara kedua makhluk yang diciptakan (laki-laki dan perempuan), baik dari segi lahiriah maupun batiniah. Oleh karena itu, timbul adanya suatu beban dan perlindungan berbeda antara suami dan istri.4 Dalam pasal 34 ayat 1 Undang-undang Nomor 1 Tahun 1974 tentang Perkawinan disebutkan bahwa: "Suami wajib melindungi istrinya dan memberikan segala sesuatu keperluan hidup rumah tangga sesuai dengan kemampuannya". Pasal di atas mengandung perintah kepada suami tentang dua hal, yaitu:

1. Melindungi, suami wajib melindungi istri. Oleh karena itu, suami ditetapkan sebagai kepala rumah tangga.

2. Memenuhi keperluan hidup, yang dapat dirinci secara lahir dan batin, suami harus memenuhi kebutuhan istrinya khususnya dan

3Ahmad Rafiq, Hukum Islam di Indonesia, (Jakarta: PT. Raja Grafindo Persada, 2003), 60 .

4Bismar Siregar, Islam dan Hukum, (Jakarta: Grafikatama Jaya, 1992), 207. 
rumah tangga pada umumnya. Mengabaikan hal tersebut berarti telah melanggar atas tanggung jawab "pelindung" rumah tangga.

Tujuan pernikahan dalam Islam bukan semata-mata untuk kesenangan lahiriyah melainkan juga membentuk suatu lembaga yang dengannya kaum laki-laki dan perempuan dapat memelihara diri dari kesesatan dan perbuatan tidak senonoh, melahirkan dan merawat anak-anak untuk melanjutkan keturunan manusia serta memenuhi kebutuhan seksual yang wajar dan diperlukan untuk menciptakan kenyamanan dan bahagia.5

Adapun menurut Zakiyah Darajat ada lima tujuan dalam perkawinan, yaitu: mendapatkan dan melangsungkan perkawinan, memenuhi hajat manusia menyalurkan syahwatnya, menumpahkan kasih sayangnya, memenuhi panggilan agama, memelihara diri dari kejahatan dan kerusakan, menumbuhkan kesungguhan untuk bertanggung jawab menerima hak serta kewajiban untuk memperoleh harta kekayaan yang halal, serta membangun rumah tangga untuk membentuk masyarakat yang tenteram atas dasar cinta dan kasih sayang.6

Perkawinan tidak hanya terjadi di waktu muda saja, tetapi pada fase dimana manusia sudah menginjak masa tua, atau biasa dikenal dengan lansia masih banyak juga di antara mereka yang masih mencari pasangan hidup, yang salah satunya telah terjadi di Kecamatan Socah Kabupaten Bangkalan. Menurut Muadz, orang yang mencapai lanjut usia sering belum siap untuk menghadapi keadaan-keadaan di masa tuanya, sehingga tidak mampu menerimanya dengan tulus.7 Bagi lansia kenyamanan dan kebahagiaan sangat dibutuhkan dalam hidupnya.

Di usia yang sudah tua, lansia sangat rentan sekali dalam berbagai aspek, terutama kesendirian diujung hidupnya. Sejalan dengan penurunan kondisi fisik ataupun mental, maka mereka (lansia) yang berstatus janda dan duda memilih menikah lagi walaupun dengan umurnya yang sudah tua. Menjadi tua umumnya

5 Abdurahman I Doi, Perkawinan dalam Syari'at Islam, terj. H. Basri Iba Asghor dan H. Cuadi Musturi, (Jakarta: Rineka Cipta, 1992), 7.

6 Zakiyah Darajat, et al., Ilmu Fikih, jilid 3, (Jakarta: Depag RI,1985), 64.

7M. Muaz Dirjowiyoto, Bagaimana Menghadapi Masalah Lanjut Usia (Nasehat Perkawinan Keluarga), (t.tp.: t.p., 1993), 54. 
dipandang sebagai proses perubahan yang pasti berlangsung di kehidupan. Menurut Undang-Undang Nomor 13 Tahun 1998 tentang Kesejahteraan Lansia, lanjut usia adalah orang yang mencapai umur 60 tahun ke atas.

Dalam tujuan perkawinan di atas terkandung aspek maqasid al-shari'ah yang tidak bisa dilepaskan, tujuan perkawinan dan maqasid al-shari'ah harus berjalan selaras karena di dalam maqasid al-shari'ah terdapat aspek-aspek yang dapat mewujudkan keluarga dengan tujuan menurut hukum Islam yang telah dipaparkan di atas. Pada prinsipnya Islam memiliki tujuan yang dapat dikristalisasikan ke dalam lima pokok pikiran, khususnya dalam tujuan perkawinan, yaitu memelihara agama, jiwa, keturunan, harta dan akal. Hal ini yang kemudian terkenal dengan istilah maqasid shari'ah.

Tujuan tersebut akan meliputi segenap ketetapan dan hukum Allah yang akan mengalami penyesuaian atau justifikasi dengan kemaslahatan manusia. Meskipun terdapat perbedaan apakah hukum Allah bergantung pada kebaikan hamba ataukah murni perintah keagamaan yang lepas dari kebaikan atau kepentingan manusia, tetapipada substansinya ulama bersepakat bahwa agama dengan perangkat hukumnya tidak membenarkan akan kemudaratan dan kerusakan, baik yang bersekala lokal, regional, terlebih yang bersifat global.

Perkawinan merupakan hal yang memuat paling tidak tiga hal dari maqasid al-shariah, yaitu memelihara agama (bifz al-din), keturunan (bifz al-nas) dan jiwa (bif₹, al-nafs). Perkawinan dapat dikatakan memelihara agama dilihat dari sisi bahwa di samping kebutuhan dan fitrah manusia, perkawinan juga merupakan ibadah serta dalam rangka menjaga individu dari kemaksiatan, zina dan tindak asusila yang diharamkan. Lebih jauh perkawinan dianggap sebagai setengah dari agama (bifz, al-din), sehingga mereka yang telah berumah tangga dipandang telah sempurna agamanya".

Dalam hal ini, dapat disimpulkan bahwa seluruh aspek pembagian dalam maqasid shariah dapat mempengaruhi atau berperan penting dalam mewujudkan keluarga yang sakinah yang akan diuraikan sebagai berikut:

1. Hifzal-din (menjaga agama), yaitu berupa tanggung jawab suami dalam menjaga dan membina keluarga tersebut untuk menjadi 
keluarga Islam sesuai dengan syariat yang telah ditetapkan oleh Allah.

2. Hifz al-nafs (menjaga jiwa), yang berupa tugas dan tanggung jawab suami dalam menjaga kemuliaan istrinya dan sebaliknya saling menjaga keluarganya agar selalu dalam keadaan yang aman dan tentram.

3. Hifz al-aql (menjaga akal), yaitu berupa saling menjaga keluarga agar tetap dalam keadaan Islam dan tidak melanggar laranganlarangan Allah, tidak berperilaku menyimpang dari syariat Islam yang telah digariskan oleh Allah.

4. Hifz al-mal (menjaga harta), yang berupa diwajibkannya suami dalam menjaga harta, dengan kata lain nafkah yang harus dipenuhi kepada istrinya walaupun dengan keterbatasan usia yang terkadang sudah tidak mampu lagi untuk bekerja.

5. Hifz al-nasl (menjaga keturunan), yaitu berupa sebuah perkawinan yang salah satu tujuannya adalah untuk menjaga keturunan, maka konsep maqasid shari'ah ini sangatlah berperan penting, dengan jumlah usia yang sudah menua suami dan istri sudah tidak dapat memberikan keturunan.

Lantas bagaimana dengan perkawinan lansia yang terjadi di Kecamatan Socah Kabupaten Bangkalan jika ditinjau dari maqasid alshari'ah akan dibahas lebih lengkap dalam artikel ini. Hal ini karena tidak menutup kemungkinan adanya penurunan fisik, sehingga berdampak pada pemenuhan hak-hak dan kewajiban lansia atau bahkan dengan tujuan terlaksananya perkawinan tersebut yang hanya karena ingin memiliki ketenangan hidup dan pendamping di masa tua.

\section{Perkawinan dalam Islam}

Kata perkawinan mengadung dua pengertian, yaitu: dalam arti yang sebenarnya (baqiqah) dan dalam arti kiasan (majaz). Dalam pengertian yang sebenarnya kata perkawinan itu berarti "berkumpul",8 sedangkan menurut empat mazhab perkawinan berarti:

8 Lily Rasjidi, Hukum Perkawinan dan Perceraian di Malaysia dan Indonesia, (Bandung: PT. Remaja Rosdakarya, 1991), 2. 
1. Akad yang memberi faedah untuk melakukan mutah secara sengaja, artinya kehalalan seorang laki-laki untuk melakukan hubungan intim dengan seorang wanita selama tidak ada faktor yang menghalangi sahnya perkawinan tersebut secara shar'i. (Imam Hanafi)

2. Akad yang menggunakan lafaz inkah yang bermakna tajwiz dengan maksud mengambil manfaat untuk bersenang-senang atau untuk mendapatkan kepuasan. (Imam Hanbali)

3. Akad yang menggunakan lafaz perkawinan atau zauj yang menyimpan arti memiliki wati. (Imam Syafi'i)

4. Akad yang mengandung arti mutah untuk mencapai kepuasan dengan tidak mewajibkan adanya harga. (Imam Maliki) 9

Pengertian perkawinan juga tertuang pada pasal 1 Undangundang Nomor 1 Tahun 1974 tentang Perkawinan sebagaimana yang telah disebutkan sebelumnya. Beberapa rumusan penting yang harus diperhatikan dalam definisi tersebut yaitu:

1. Kata "Seorang pria dengan seorang wanita", maksudnya perkawinan hanyalah antara dua jenis kelamin yang berbeda, sehingga menolak perkawinan beda jenis.

2. Kata: "sebagai suami istri", maksudnya bahwa dengan perkawinan itu bertemu dengan dua jenis kelamin yang berbeda dalam suatu rumah tangga bukan hanya dalam istilah "hidup bersama".

3. Tujuan perkawinan yaitu: "membentuk keluarga (rumah tangga) yang bahagia dan kekal", maksudnya menafikan suatu perkawinan yang hanya untuk waktu tertentu (temporal), seperti kawin mutah atau kawin tablil.

4. Kata "Berdasarkan Ketuhanan Yang Maha Esa", maksudnya perkawinan dalam Islam adalah suatu peristiwa agama dan dilakukannya untuk mentaati perintah Allah.10

Selain itu, definisi perkawinan juga tertuang pasal 2 Kompilasi Hukum Islam (KHI), yang berbunyi: "Perkawinan menurut hukum Islam adalah perkawinan, yaitu akad yang sangat kuat atau mitsaqan

9Abdurahman al-Jaziri, Kitabul Fiqh ala Mazahib al-Arba'ah, juz 4, (Mesir: AlMaktabah at-Tajiriyyatul Kubra, t.t.), 2.

10Muhammad Ra'fat 'Utsman, Fikih Khitbah dan Perkawaninan (Edisi Perempuan), (Depok: Fathan Media Prima, 2017), 4. 
ghaliz̧han untuk mentaati perintah Allah dan melaksanakannya merupakan ibadah." Adapun rumusan penting yang harus diperhatikan dalam definisi tersebut yaitu digunakan kata: "mithaqan ghalidan", yang maksudnya akad perkawinan itu suatu akad yang sangat kuat, religius, menghalalkan hubungan kelamin seorang pria dengan seorang wanita dan yang melakukannya hanya semata- mata karena beribadah kepada Allah.11

Para ulama telah sependapat bahwa perkawinan itu disyariatkan oleh agama, perselisihan mereka di antaranya dadalah dalam hal hukum perkawinan.12 Hukum perkawinan akan berbeda, tergantung dengan kadar kemampuan baik, lahir maupun batin masing-masing individu, artinya masing-masing individu memilki pertimbangan hukum perkawinan yang beerbeda untuk dirinya, sesuai dengan kelima hukum yang ada dalam Syariat, yaitu:

1. Wajib

Perkawinan menjadi wajib bagi orang yang sudah sanggup secara materiil maupun moriil dan ia takut akan jatuh dalam jurang perzinaan. Selain itu, tidak ada niat untuk menyakiti wanita yang nantinya menjadi istrinya atau melalaikan kewajiban sebagai suami. Adapun yang lebih penting lagi adalah ia sudah tidak sanggup lagi menahan hasrat seksualnya, meskipun dengan berpuasa.13 Oleh karena itu, jika tidak ada jalan lain untuk meraih kesucian, kecuali dengan perkawinan, maka perkawinan tersebut hukumnya adalah wajib bagi yang bersangkutan.

2. Sunnah

Perkawinan sangat dianjurkan bagi siapa saja yang memiliki hasrat atau dorongan seksual untuk perkawinan dan memiliki kemampuan untuk melakukannya, walaupun merasa yakin akan kemampuannya mengendalikan dirinya sendiri, sehingga tidak khawatir akan terjerumus dalam perbuatan yang diharamkan Allah. Orang seperti ini, tetap dianjurkan untuk menikah, sebab

11 Ibid., 5.

12Abd.Shomad, HukumIslam Penormaan Prinsip Syariah dalam Hukum Indonesia, (Jakarta:Kencana, 2010), 282

13Fahd bin Abdul Karim bin Rasyid as-Sanidy, Indabnya Perkawaninan Sambil Kuliah, (Jakarta: Cendekia Sentra Muslim, 2005), 33. 
bagaimanapun perkawinan tetap lebih utama daripada mengkontrasikan diri secara total untuk beribadah.14

3. Makruh

Jika seseorang laki-laki yang tidak mempunyai syahwat untuk melaksanakan perkawinan dengan seseorang perempuan atau sebaliknya sehingga tujuan perkawinan yang sebenarnya tidak akan tercapai, maka yang demikian itu hukumnya makruh.15 Juga pada laki-laki yang sebetulnya tidak membutuhkan perkawinan, baik disebabkan tidak mampu memenuhi hak calon istri yang bersifat nafkah lahir maupun yang tidah memiliki hasrat seksual, sementara perempuan tidak terganggu dengan ketidakmampuan sang calon suami. 16

4. Haram.

Perkawinan menjadi haram bila dilakukan oleh orang yang mempunyai niat menzhalimi istrinya17 dan bagi orang yang tidak mempunyai keinginan serta tidak mempunyai tanggung jawab untuk melaksanakan kewajiban-kewajiban dalam rumah tangga, sehingga apabila ia melangsungkan perkawinan dirinya dan istrinya akan terlantar. Demikian juga apabila seseorang, baik pria maupun wanita yang mengetahui bahwa dirinya mempunyai penyakit atau kelemahan yang mengakibatkan tidak dapat melaksanakan tugasnya sebagai suami/istri dalam perkawinan, sehingga mengakibatkan salah satu pihak menjadi menderita.18

5. Mubah.

Perkawinan hukumnya menjadi mubah bagi orang yang mempunyai kemampuan untuk menikah, tetapi apabila tidak melakukannya tidak khawatir akan berbuat zina. Hukum mubah juga bagi orang yang antara pendorong dan penghambat untuk menikah adalah sama, sehingga menimbulkan keraguan bagi orang yang melakukannya, seperti orang yang mempunyai

14Ibid,. 4-5.

15Pakih Sati, Panduan Lengkap Perkawaninan: Fiqh Munakahat Terkini, Jogjakarta: Bening, 2011), 21.

16Muhammad Bagir, Fiqih Praktis II: Menurut Al-Qur'an, As-Sunnah dan Pendapat Para Ulama', (Bandung: Karisma, 2008), 6-7.

17Sulaiman Rasjid, Figh Islam, (Bandung: Sinar Baru Algensindo, t.t.), 382.

18Pakih Sati, Panduan Lengkap Perkawaninan...,22. 
keinginan tetapi belum mempunyai kemampuan, sebaliknya bagi orang yang mempunyai kemampuan untuk menikah tetapi belum mempunyai kemauan yang kuat.19

Jumhur ulama sepakat bahwa rukun perkawinan itu terdiri atas:

1. Adanya calon suami dan isteri yang akan melakukan perkawinan.

2. Adanya wali dari pihak calon pengantin wanita.

3. Adanya dua orang saksi.

4. Sighat akad perkawinan, yaitu ijab kabul yang diucapkan oleh wali atau wakilnya dari pihak wanita, dan dijawab oleh calon pengantin laki-laki.20

Dengan beberapa syarat berikut:

1. Bagi calon mempelai pria disyaratkan beragama Islam, laki-laki, jelas orangnya, cakap bertindak hukum untuk hidup berumah tangga, dan tidak terdapat halangan perkawinan.

2. Bagi calon mempelai wanita disyaratkan beragama Islam, perempuan, jelas orangnya, dapat dimintai persetujuan, dan tidak terdapat halangan perkawinan.

3. Bagi wali dari calon mempelai wanita disyaratkan laki-laki, beragama Islam, mempunyai hak perwaliannya, dan tidak terdapat halangan untuk menjadi wali.

4. Saksi perkawinan disyaratkan minimal dua orang saksi, menghadiri ijab qabul, dapat mengerti maksud akad, beragama Islam, dan balig.

5. Shighat perkawinan disyaratkan jelas dan bersambung.21

\section{Maqasid al-Shari'ah dalam Islam}

Maqashid al-shariah terdiri dari dua kata, yaitu maqasid dan alShari'ah. Kata maqasid merupakan jamak dari kata maqasad yang berarti maksud dan tujuan dan kata shari'ah yang berarti hukum Allah Swt. baik yang ditetapkan sendiri oleh Allah, maupun ditetapkan Nabi sebagai penjelasan atas hukum yang ditetapkan Allah atau dihasilkan oleh mujtahid berdasarkan apa yang ditetapkan

19Abdurahman al-Jaziri, Kitabul Figh ala Mazabib al-Arba'ah..., 12. 20 Abd. Rahman Ghazaly, Figh Munakahat, (Jakarta: Kencana, 2006), 45-46.

21 Zainuddin Ali, Hukum Perdata Islam di Indonesia, (Jakarta: Sinar Grafika, 2007), 21. 
Allah atau dijelaskan oleh Nabi. Hakikat dari maqasid adalah kemaslahatan. Dengan demikian, kata maqashid al-shari ab berarti apa yang dimaksud oleh Allah Swt. dalam menetapkan hukum, apa yang dituju Allah dalam menetapkan hukum atau apa yang ingin dicapai oleh Allah dalam menetapkan suatu hukum.22

Dalam hal ini, Imam Al-Shatibi sebagai pencetusnya mengemukakan definisi secara spesifik tentang maqasid al-shari'ah disebabkan karena masyarakat umum sudah memahaminya baik langsung maupun tidak langsung, 23 sedangkan menurut ulama lain, yaitu Ibnu 'Asyur mendefinisikannya sebagai segala pengertian yang dapat dilihat pada hukum-hukum yang disyariatkan, baik secara keseluruhan atau sebagian, dan terbagi mejadi maqasid umum dan maqasid khusus. Maqasid umum dapat dilihat dari hukum-hukum yang melibatkan semua individu secara umum, sedangkan maqasid khusus cara yang dilakukan oleh syariat untuk merealisasikan kepentingan umum melalui tindakan seseorang.24

Maqasid shari'ah sendiri dibagi menjadi tiga tingkatan dalam usaha mencapai tujuan persyariatan hukum yang utama yaitu untuk mewujudkan kemaslahatan manusia. Ketiga tingkatan tersebut yaitu: 1. Maqasid Daruriyah

Daruriyah merupakan tujuan yang harus mutlak ada/tujuan primer, sehingga jika tujuan ini nihil (tidak ada), maka akan berakibat fatal karena terjadinya kehancuran dan kekacauan secara menyeluruh.25 Menurut Imam Abu ishaq asy-Syatibi (w. $790 \mathrm{H}$ ), ada lima perkara yang harus mendapat prioritas perlindungan, yaitu:

a. Memelihara agama (bifzal-din)

Menjaga agama merupakan persatuan akidah, ibadah, hukum dan undang-undang yang telah disyariatkan oleh

22Amir Syarifuddin, Ushul Fiqh, (Jakarta: Kencana Prenadamedia Group, 2008), 231.

23Muhammad Thahir bin 'Asyur, Maqashid al-Syari'ah al-Islamiyyah, (t.tp.: Dar alNafa'is, 2001),194.

24 Ibid., 195.

25 Wael B. Hallaq, Sejarah Teori Hukum Islam, Pengantar untuk. Usul Fiqib Mazhab Sunni, terj. E. Kusnadiningrat dan Abdul haris bin Wahid, Jakarta: PT. Raja Grafindo Persada, 2010), 248. 
Allah Swt. untuk mengatur hubungan manusia dengan tuhannya dan hubungan antara sesama manusia. Untuk mewujudkan dan mendirikan agama, Islam telah mensyariatkan kewajiban dan lima hukum fundamental yang merupkan sendi Islam dan juga akidah-akidah lain serta pokok-pokok ibadah dengan tujuan menegakkan agama dan meneguhkannya dalam hati dan mengikuti hukum, yang mana manusia tidak bisa baik kecuali dengan hukum-hukum itu.

b. Memelihara akal (hifz, al-aq)

Menjaga agar terpeliharanya akal yang diciptakan Allah Swt. khusus bagi manusia. Dengan akal manusia dapat membedakan mana yang baik dan mana yang buruk, maka pertimbangan akan pemeliharaan akal sangatlah diperlukan. Bagi manusia diharuskan berbuat segala sesuatu untuk menjaga keberadaannya dan meningkatkan kualitasnya dengan cara menuntut ilmu. Dalam hal ini manusia dituntut untuk menimba ilmu tanpa batas usia dan tidak memperhitungkan jarak atau tempat.26

c. Memelihara Harta (bifz al-mal)

Untuk memlihara hidup, manusia memerlukan sesuatu yang dapat digunakan untuk memenuhi kebutuhan hidupnya, seperti makan, minum, dan pakaian, untuk itu diperlukan harta, sehingga manusia harus berupanya mendapatkannya secara halal dan baik. Pencarian harta yang halal dan baik adalah perbuatan yang diwajibkan oleh Allah Swt., sehingga pemeliharaan harta merupakan salah satu bentuk kebutuhan manusia yang tidak dapat dipisahkan dengan kehidupan.

d. Memelihara keturunan (bifz al-nas)

Memelihara keturunan termasuk bagian dari kebutuhan primer. Keturunan inilah yang akan melanjutkan generasi manusia di muka bumi. Oleh karena itu, Islam mengatur masalah perkawinan dengan berbagai persyaratan di dalamnya. Islam melarang berzina karena dianggap

26 Amir Syarifuddin, Usul Fiqh Jilid II, (Jakarta: Kencana 2011), 224. 
mengotori kemuliaan manusia. Dari sinilah dapat dipahami mengapa perkawinan itu diperintahkan sedangkan perzinaan itu dilarang dalam Islam.

e. Menjaga jiwa (bifz, al-nafs)

Memelihara hak untuk hidup secara terhormat dan memelihara jiwa agar terhindar dari tindakan penganiayaan, berupa pembunuhan, pemotongan anggota badan maupun tindakan melukai, termasuk juga memelihara kemuliaan atau harga diri manusia dengan jalan mencegah perbuatan qazaf, mencaci maki serta perbuatan-perbuatan serupa.27

2. Maslabah Hajizat

Al-Syatibi mendefinisikan maslahah hajiyat sebagai kebutuhan sekunder. Jika kebutuhan ini tidak terpenuhi keselamatan manusia tidak sampai terancam namun ia akan mengalami kesulitan. Syariat Islam menghilangkan segala kesulitan tersebut dengan adanya hukum rukhsah (kemudahan) yang memberi kelapangan dalam kehidupan manusia.

3. Maslabab Tabsiniyat

Maslahab Tabsiniyat didefinisikan sebagai kebutuhan yang tidak mengancam eksistensi salah satu dari lima hal pokok tadi dan tidak pula menimbulkan kesulitan apabila tidak terpenuhi. Tingkat kebutuhan ini berupa kebutuhan pelengkap, seperti dikemukakan al -yatibi seperti hal yang merupakan kepatutan menurut adat-istiadat, menghindari hal yang tidak enak dipandang mata dan berhias dengan keindahan yang sesuai dengan tuntutan norma dan akhlak, dalam berbagai bidang kehidupan seperti ibadah muamalah, dan uqubah.28

Dalam tinjauan global, hukum Islam memiliki tujuan untuk kemaslahatan manusia seluruhnya dalam menetapkan sebuah hukumnya, baik itu kemaslahatan di dunia ataupun di hari yang kekal (akhirat).29 Hal itu dapat dilihat dari persoalan pengutusan Rasul

27 Ali Sodiqin, Fiqh Usul Figh: Sejarah, Metodologi dan Implementasinya di Indonesia, (Yogjakarta: Berada Publishing, 2012), 172-173.

28 Ibid, 174.

29 Ismail Muhammad Syah, Filsafat Hukum Islam, (Jakarta: Bumi Aksara,1992), 65. 
oleh Allah, yang tertuang dalam firman-Nya pada surah An-Nisa' ayat 165 yang artinya:30

(mereka Kami utus) selaku Rasul-rasul pembawa berita gembira dan pemberi peringatan agar supaya tidak ada alasan bagi manusia membantah Allah sesudah diutusnya Rasul-rasul itu. dan adalah Allah Maba Perkasa lagi Maha Bijaksana.

Tujuan hukum/maqasid shari'ah tersebut harus diketahui oleh mujtahid dalam rangka mengembangkan pemikiran hukum dalam Islam secara umum dan menjawab persoalan-persoalan hukum kontemporer yang kasusnya tidak diatur secara eksplisit oleh alQur'an dan hadis. Lebih dari itu, tujuan hukum harus diketahui dalam rangka mengetahui, apakah suatu kasus masih dapat diterapkan berdasarkan ketentuan hukum, karena adanya perubahan struktur sosial atau tidak.31 Dengan demikian, hukum Islam akan tetap dinamis dalam menjawab berbagai fenomena social yang senantiasa berubah dan berkembang. 32

\section{Perkawinan Lansia di Kecamatan Socah Kabupaten Bangkalan}

Kecamatan Socah adalah salah satu wilayah di Kabupaten Bangkalan, pulau Madura, Provinsi Jawa Timur. Kecamatan Socah memiliki luas wilayah $53.82 \mathrm{~km} 2$, yang secara administratif pemerintah terbagi menjadi 11 desa dengan jumlah penduduk sebanyak 90.223 Jiwa. Kecamatan Socah terdiri dari hamparan daratan tanah darat yang sebagiannya adalah tanah sawah, perkebunan tambak dan pemukiman penduduk serta beberapa desanya terletak di wilayah pesisir.

Dilihat dari jumlah penduduknya, mayoritas adalah perempuan dan dilihat dari mata pencahariannya sebagian besar penduduknya bekerja merantau, bertani dan swasta, sebagian lainnya memiliki pencaharian yang beagam antara lain pegawai negeri sipil,

30 Departemen Agama Republik Indonesia, Al Qur'an dan Terjemahnya, (Jakarta: t.p.: 1996), 151.

31 Fathurrahman Djamil, Filsafat Hukum Islam, Jakarta: Logos Wacana Ilmu,1997), 124.

32 Nasrun Rusli, Konsep Ijtibad al-Syaukani Relevansinya bagi Pembaharuan Hukum Islam di Indonesia, (Jakarta: Logos Wacana Ilmu, 1999), 44. 
wiraswasta, dosen, wirausaha dan nelayan. Adapun mayoritas penduduknya menganut agama Islam.

Adapun tingkat pendidikan penduduk Kecamatan Socah ini cukup baik, sebab ada beberapa warga penduduknya merupakan lulusan Perguruan Tinggi dari berbagai Universitas atau Institut, di antaranya Unair, Unesa, Untag, UIN Surabaya, UPN dan lain-lain. Apalagi setelah berdirinya Universitas Negeri Trunojoyo mempermudah penduduk Kecamatan Socah untuk melanjutkan pendidikannya ke jenjang yang lebih tinggi dengan biaya yang lebih murah. Di Kecamatan Socah sendiri telah ada berbagai lembaga pendidikan, dari tingkat Paud sampai SMA.

Sebagaimana yang diketahui sebelumnya, perkawinan lansia adalah perkawinan yang dilangsungkan pada umur 60 tahun ke atas, baik salah satu mempelai atau keduanya. Terdapat tiga pasangan lansia yang melangsungkan perkawinan. Ketiganya telah dilakukan sesuai rukun dan syarat yang ditetapkan oleh agama, serta disertai adanya pemberian mahar berupa uang. Dalam pelaksaannya, perkawinan lansia ini mengundang pegawai pencatat nikah (PPN), atau dengan kata lain telah dicatatkan di KUA pada tahun 2017. Adapun penjelasan dari ketiga perkawinan lansia yang dimaksud adalah:

1. Pasangan Sumarsono 63 tahun dengan Hosyah 46 tahun

Dalam perkawinan ini, Sumarno masih sanggup untuk memenuhi hak dan kewajibannya. Tidak ada keluhan mengenai kebutuhan materi karena faktor lingkungan desa yang memungkinkan penanaman sayur sendiri dan dekat dengan ekosistem laut, sehingga bahan-bahan baku makanan sangatlah murah. Adapun dalam memenuhi hak dan kewajiban non materi, Sumarsono masih kuasa melakukan hubungan intim walaupun sering mengeluh sakit pinggang, sehingga tidak dapat sesempurna seperti masih muda.

Dalam hal ini, Hosyah mengatakan bahwa dirinya ditekan oleh orang tuanya untuk menikah agar tali persaudaraan antara keluarganya dengan keluarga Sumarsono tidak terputus. Keduanya merupakan sepupu. Hosyah tidak dengan berat hati menerima perkawinan tersebut karena orang tuanya yang sudah tua, sehingga sampai saat ini belum ada kerelaan dan keikhlasan 
dalam menjalani perkawinannya. Meskipun Sumarsono telah berprilaku sangat baik terhadapnya, Hosyah masih tidak dapat merasakan arti sebuah keluarga dan merasa asing dengan suaminya sendiri, sehingga dia memilih untuk selalu diam kecuali diajak bicara, sedangkan Sumarsono sendiri hanya beranggapan bahwa ini hanyalah permasalahan terbiasa, lambat laun Hosyah pasti akan sadar dan dapat menerima dirinya seutuhnya sebagai suami walaupun terkadang dirinya merasa bersalah dengan perkawinan tersebut. Perkawinan semacam ini yang membuat sebuah keluarga sulit untuk mencapai sakinah.

2. Pasangan Angwar 64 tahun dengan Seujeh 36 tahun

Angwar merupakan salah satu nelayan di daerah pesisir selatan Kecamatan Socah. Malamnya dia bekerja serabutan di pasar sebagai kuli panggul. Setelah menikahi istrinya, dia menetap di rumahnya sendiri dengan 1 orang anaknya, sedangkan 2 anak lainnya sudah berkeluarga dan memiliki rumah sendiri. Antara Angwar dan Seujeh masih ada hubungan keponakan.

Dalam pemenuhan hak dan kewajiban, baik dari pihak suami atau istri antara pasangan Angwar dan Seujeh dapat dikatakan sangat sempurna karena Angwar semakin giat dalam mencari nafkah untuk kebutuhan sehari-hari, begitu juga dengan Seujeh yang melaksanakan hak-hak dan kewajibannya dengan baik, sehingga keadaan keluarga ini sangat bahagia. Adapun tentang pemberian nafkah bathin, Angwar masih bisa melaksanakannya walaupun tidak sesempurna dan sebugar waktu masih muda. Hal ini, dimaklumi Saejeh karena akan berdampak pada kesehatan Angwar jika tetap dipaksakan.

Di lain kesempatan, Seujeh mengatakan bahwa sikap Angwar sebagai suami telah mencerminkan sikap imam yang baik dalam keluarga, tetapi ada satu hal yang masih belum menemukan jalan keluar dan mencapai kesepakan, yaitu perihal tidak memiliki anak lagi karena beberapa pertimbangan. Saujeh tidak dapat menerima keputusan Angwar untuk tidak perlu memiliki anak karena dirinya merasa masih mampu dan sangat memiliki keturunan dari perkawinan tersebut, mengingat dirinya adalah perawan dan sangat menginginkan kehadiran anak. Hal ini yang menyebabkan akhir-akhir ini Seujeh masih tidak ingin 
bicara terlalu banyak dengan Angwar. Adapun yang sebenarnya menjadi alasan Angwar untuk tidak ingin memiliki anak, yaitu khawatir akan ketidakmampuannya menafkahi dan menyekolahkan, karena keadaan Angwar yang sekarang hanya petani dan pekerja serabutan di pasar.

3. Pasangan Ahmad 66 tahun dengan Maisaroh 50 tahun

Dalam pemenuhan hak-hak dan kewajiban kedua pasangan tersebut tidak ada sebuah permasalahan, baik nafkah batin maupun lahir. Nafkah lahir yang diberikan Ahmad selalu lebih dari cukup karena faktor usia yang membuat Maisaroh tidak membutuhkan banyak biaya terlebih lagi semua anak- anak dari Maisaroh dan Ahmad sudah menikah dan memiliki rumah sendiri.

Ahmad secara pribadi menuturkan tentang ketidakinginanya untuk memiliki anak karena beberapa faktor, yaitu faktor usia yang sudah sangat lanjut dan ketakutan akan biaya hidup anak ketika beranjak dewasa, walapun dalam hal ini sudah ada beberapa anak dari perkawinan Ahmad sebelumnya yang sanggup membiayai adiknya tersebut. Ketidakinginan untuk memiliki anak tersebut telah menjadi kesepakatan bersama, meskipun terdapat sedikit kekecewaan dari Mawsaroh karena memiliki keturunan dari Ahmad yang merupakan orang yang sangat baik dan saleh tentulah menjadi keinginannya. Hal ini tidak lantas menimbulkan kebencian Maesaroh terhadap Ahmad katena salah satu tujuannya menikah hanya ingin menghabiskan waktu bersama di masa tuanya. Walaupun keinginannya untuk memiliki anak sudah ditolak tetapi dirinya masih berusaha untuk terus membujuk suaminya agar mengubah kesepakatan sebelumnya.

\section{Perkawinan Lansia di Kecamatan Socah Kabupaten Bangkalan dalam Perspektif Maqasid al-Shari'ah}

Tujuan Allah mensyari'atkan hukum-Nya adalah untuk memelihara kemaslahatan manusia untuk menghindari keburukan ataupun gabungan keduanya sekaligus, baik di dunia maupun di akhirat. Tujuan tersebut hendak dicapai melalui taklif yang pelaksanaannya sangat tergantung pada pemahaman sumber hukum yang utama, yaitu al-Quran dan hadis. Adapun dalam rangka 
mewujudkan kemaslahatan di dunia dan di akhirat, berdasarkan penelitian para ahli ushul fikih, ada lima unsur pokok yang harus dipelihara dan diwujudkan, yaitu agama, jiwa, akal, keturunan, dan harta sebagaimana yang terkandung dalam kajian maqasid al-shari'ah. Seorang mukallaf akan memperoleh kemaslahatan, manakala dapat memelihara kelima aspek pokok itu, sebaliknya ia akan merasakan adanya keburukan, manakala tidak dapat memeliharanya dengan baik.33

Berbicara tentang perkawinan tidak akan dapat dilepaskan dari beberapa unsur, yaitu: tujuan, syarat dan rukun yang menentukan sah tidaknya suatu perkawinan. Adapun mengenai perkawinan lansia perlu mendapatkan perhatian khusus karena tidaklah menutup kemungkinan karena faktor usia yang sudah mulai menua mengakibatkan turunya kondisi fisik yang dapat mempengaruhi dalam pemenuhan hak dan kewajibannya sebagai pasangan.

Jika ditinjau dari maqasid shariah, dapat disimpulkan beberapa hal terkait perkawinan lansia yang dilaksanakan di Kecamatan Socah Kabupaten Bangkalan:

1. Hifz, al-din (menjaga agama).

a. Pasangan Sumarsono 63 tahun dengan Hosyah 46 tahun: Perkawinan antara Sumarsono dan Hosyah telah dilaksanakan secara resmi menurut agama maupun negara sehingga semua yang bersangkutan dengan syarat dan rukunnya telah terpenuhi.

b. Pasangan Angwar 64 tahun dan Seujeh 36 tahun: Pasangan Angwar dan Seujeh telah memenuhi rukun dan syarat perkawinan sehingga dapat melaksanakan perkawinan di KUA dan telah dinyatakan sah baik menurut agama maupun negara.

c. Pasangan Ahmad 68 tahun dengan Maisaroh 41 tahun: Pasangan Ahmad dan Maisaroh telah melaksanakan perkawinan baik sesuai agama maupun Negara sehingga perkara yang berkaitan dengan hal-hal yang bersangkutan dengan syarat dan rukun pernikahan telah terpenuhi.

2. Hifz al-mal (menjaga harta).

33 Faturrahman Djamil, Metode Ijtihad Majlis Tarjih Muhammadiyah, (Jakarta: Logos, 1995), 39. 
a. Pasangan Sumarsono 63 tahun dengan Hosyah 46 tahun: Sumarsono dapat memenuhi nafkah dengan baik walaupun pekerjaannya bukanlah pekerjaan yang bisa mendapatkan gaji dengan nominal yang tetap setiap harinya.

b. Pasangan Angwar 64 tahun dan Seujeh 36 tahun: Angwar dapat memenuhi kewajiban materinya dengan bekerja keras sebagai nelayan di daerah pesisir selatan Kecamatan Socah dan bekerja serabutan di pasar sebagai kuli panggul pada malam hari.

c. Pasangan Ahmad 68 tahun dengan Maisaroh 41 tahun: Ahmad sebagai pedagang dayur di pasar selalu dapat memenuhi kebutuhan Maisaroh, bahkan menurut penuturan istrinya nafkah yang diberikan lebih dari cukup karena faktor usia yang menyebutkan tidak banyak memerlukan biaya terlebih lagi semua anak- anak dari Maisaroh dan Ahmad sudah menikah dan memiliki rumah sendiri.

3. Hifz al-nasl (menjaga keturunan).

a. Pasangan Sumarsono 63 tahun dengan Hosyah 46 tahun: Walaupun terdapat unsur ketidakrelan Hosyah menikah dengan Sumarsono tetapi Hosyah tetap melaksanakan kewajiban melayani suami.

b. Pasangan Angwar 64 tahun dan Seujeh 36 tahun: Angwar menolak untuk tidak memiliki anak karena ketakutannya tidak dapat menafkai anaknya mengingat usianya yang semakin menua. Hal ini masih belum dapat diterima oleh Seujeh karena menurutnya masih mampu dan sangat menginginkan memiliki keturunan dalam perkawinan tersebut.

c. Pasangan Ahmad 68 tahun dengan Maisaroh 41 tahun: Pasangan Ahmad dan Maisaroh telah sepakat untuk tidak memiliki anak karena faktor usia yang sudah lanjut, namun di sisi lain Maisaroh diam-diam masih menginginkan anak dari Ahmad sehingga sampai saat ini masih mencoba membujuk Ahmad untuk mau memiliki keturunan lagi.

4. Hifz al-aql (menjaga akal) dan Hifź al-nafs (menjaga jiwa).

a. Pasangan Sumarsono 63 tahun dengan Hosyah 46 tahun: Pada pasangan Sumarsono dan Hosyah terjadi kesenjangan di antara keduanya karena pada dasarnya Hosyah ditekan oleh 
orang tuanya untuk menikah dengan Sumarsono agar supaya tali persaudaraan antara keluarga Sumarsono dan Hosyah tidak putus. Hal itulah yang menyebabkan Hosyah masih merasa asing dengan suaminya sendiri dan terjadilah ketidakrukunan antara kedua belah pihak.

b. Pasangan Angwar 64 tahun dan Seujeh 36 tahun: Ketidakinginan Angwar untuk memiliki anak yang akhirnya menimbulkan kekecewaan bagi Seujeh sehingga Seujeh sendiri masih sedikit enggan untuk berinterkasi dengannya sebagaimana pada awal menikah dulu. Dalam hal ini, tidak ada yang mau mengalah di antara keduanya.

c. Pasangan Ahmad 68 tahun dengan Maisaroh 41 tahun: Kehidupan pasangan Ahmad dan Maisaroh berjalan sesuai dengan yang direncanakan ketika sebelum menikah, sehingga hati dan jiwa mereka tenang kecuali satu hal yang terkadang dipikirkan oleh Maisaroh tentang keinginannya memiliki anak. Dari penjabaran perkawinan lansia di atas, tampak dengan jelas beberapa hal:

1. Menikah karena tekanan orang tua yang berdampak pada terganggunya kesakinahnya keluarga.

2. Ketidakinginan memiliki keturunan karena faktor usia yang semakin menua sehingga timbul kekhawatiran tidak dapat menafkahi anak.

Allah Swt. tidak menjadikan manusia seperti makhluk lainnya yang hidup bebas mengikuti nalurinya dan berhubungan tanpa aturan. Demi menjaga kehormatan dan martabat kemuliaan manusia, Allah mengadakan hukum sesuai dengan martabatnya, sehingga hubungan antara laki-laki dan perempuan diatur secara terhormat dan berdasarkan rasa saling meridhoi, dengan upacara ijab dan kabul sebagai lambang adanya rasa ridho-meridhoi dan dengan dihadiri para saksi yang menyaksikan bahwa pasangan laki-laki dan perempuan itu telah saling terikat.

Dalam sebuah perkawinan tidaklah lepas dari beberapa persyaratan yang harus dipenuhi salah satunya adalah adanya bentuk kerelaan pasangan dan tidak adanya unsur paksaan dari siapapun dalam melangsungkan perkawinan tersebut demi terbentuknya tujuan perkawinan yang sakinah. Hukum larangan perkawinan 
dengan paksaan telah dijelaskan dalam beberapa hadis dari Ibnu Abbas r.a bahwasannya Nabi saw. bersabda yang artinya:

"Seorang janda lebih berhak atas dirinya daripada walinya, sedangkan seorang perawan maka ayahnya harus meminta persetujuan dari dirinya, dan persetujuannya adalah diam." 34

Adapun menurut tinjauan maqasid al-shari'ah, tindakan paksaan akan menimbulkan kalutnya pikiran karena ketidakserasian dan kecocokan antara kedua pasangan dalam mengarungi bahtera kehidupan yang juga akan mempengaruhi tujuan-tujuan yang telah ditentukkan oleh Islam. Dalam konsep maqasid al-shariah, pemaksaan dalam menikah sudah menyalahi kaidah yaitu bifz al-aql (menjaga pikiran) karena segala bentuk keburukan berawal dari pikiran.

Adapun dalam kasus ini objek memilih untuk tidak meneruskan garis keturunannya atau tidak ingin memiliki anak dengan alasan umur dari suami yang sudah mulai menua sehingga suami merasa takut akan ketidaksanggupannya dalam menafkahi dan menyekolahkan anak tersebut, seperti anak-anak pada umumnya. Hal ini bertentangan dengan salah satu pembagian maqasid al-shari'ah, yaitu hif₹, al-nasl (menjaga keturunan) agar dapat menjadi penerus umat Islam. Akan tetapi, pada sisi lain dalam al-Quran dan hadis, terdapat ayat-ayat yang berindikasi tentang diperbolehkannya menghentikan reproduksi, yakni karena mengkhawatirkan beberapa hal-hal berikut:

1. Keselamatan jiwa atau kesehatan ibu.

2. Keselamatan agama, akibat kesempitan penghidupan.

3. Kesehatan atau pendidikan anak-anak bila jarak kelahiran anak terlalu dekat.

Hal ini sebagaimana pendapat Imam Al-Ghazali, Syaikh AlHariri dan Syaikh Syaltut yang membolehkan menghentikan reproduksi atau menunda dengan ketentuan antara lain, untuk menjaga kesehatan ibu, menghindari kesulitan ibu, dan untuk menjarangkan anak. Mereka juga berpendapat bahwa perencanaan keluarga itu tidak sama dengan pembunuhan, karena pembunuhan itu berlaku ketika janin mencapai ke tujuh dari penciptaan, dan

34 Ibid., 138. 
dalam kasus ini, ayah yang merasa keberatan karena kekhawatirannya tidak dapat menyekolahkan anaknya tersebut, seperti anak-anak lain pada umumnya.

\section{Kesimpulan}

Perkawinan lansia yang dikaji memiliki 3 obyek penelitian, yang semuanya sudah resmi menikah di kantor Kantor Urusan Agama Kecamatan Socah Kabupaten Bangkalan pada tahun 2017, yaitu: 1) Sumarsono (63) dan Hosyah (46) yang menikah dengan latar belakang agar tali silaturrahim antar keluarga tidak putus dengan menekan mempelai wanita, sehingga menyebabkan adanya ketidakrelaan darinya; 2) Angwar (64) dan Seujeh (36) yang menikah atas dasar belas kasihan dan dorongan keluarga karena mempelai wanita adalah perawan tua dan masih keponakannya sendiri; 3) Ahmad (66) dan Maisaroh (50) yang menikah atas dasar saling suka, menghindari kemaksiatan dan mencari ketenangan hidup di masa tua. Ketiga pasangan tersebut dapat memenuhi hak dan kewajiban, baik materi maupun non materi, meskipun tidak sesempurna pasangan muda. Akan tetapi, beberapa suami tidak menginginkan memiliki anak karena adanya kekhawatiran tidak mampu menafkai, padahal istri sangat mengharapkannya.

Dengan demikian, dapat disimpulkan bahwa perkawinan lansia di Kecamatan Socah tersebut adakalanya sesuai dan tidak sesuai dengan maqasid al-shari'ah. Kesesuaian yang dimaksud adalah dari segi bifz al-din dan bifz al-mal, sedangkan ketidaksuainnya terlihat dari segi hif, al-nasl karena tidakinginnya memiliki keturunan dan dari segi hifz al-nafs dan bifz al-'aql, karena adanya perbedaan pendapat terkait keturunan bardampak pada ketidakharmonisan keluarga yang dapat mengganggu jiwa dan akal. Dalam hal ini, seharusnya diadakan dialog dan pendekatan yang intens kepada pasangan agar dapat lebih memahami dan saling terbukasatu sama lain.

\section{Daftar Pustaka}

Abdurahman al-Jaziri. Kitabul Figh ala Mazabib al-Arba'ah, juz 4, Mesir: Al-Maktabah At-Tajiriyyatul Kubra, t.t.

Abdurahman I Doi. Perkawinan dSyariat Islam, terj. H. Basri Iba Asghor dan H. Cuadi Musturi, Jakarta: Rineka Cipta, 1992. Abd. Rahman Ghazaly. Fiqh Munakahat, Jakarta: Kencana, 2006. 
Abd. Shomad. Hukum Islam Penormaan Prinsip Syari'ah dalam Hukum Indonesia, Jakarta: Kencana, 2010.

Ahmad Rafiq. Hukum Islam di Indonesia, Jakarta: PT. Raja Grafindo Persada, 2003.

Ali Sodiqin. Fiqh Usul Fiqh: Sejarah, Metodologi dan Implementasinya di Indonesia, Yogjakarta: Berada Publishing, 2012.

Amir Syarifuddin. Ushul Fiqh, Jakarta: Kencana Prenadamedia Group, 2008.

-----. Usul Fiqh Jilid II, Jakarta: Kencana 2011.

Badan Penasehat Pembinaan dan Pelaksanaan Perkawinan.

Tuntunan Praktis Rumah Tangga Bahagia, Sidoarjo: BP4, 2012.

Bismar Siregar. Islam dan Hukum, Jakarta: Grafikatama Jaya, 1992.

Departemen Agama Republik Indonesia. Al Qur'an dan Terjemabnya, Jakarta: t.p.: 1996.

Fahd bin Abdul Karim bin Rasyid as-Sanidy. Indabnya Perkawaninan Sambil Kuliah, Jakarta: Cendekia Sentra Muslim, 2005.

Fathurrahman Djamil. Filsafat Hukum Islam, Jakarta: Logos Wacana Ilmu,1997.

-----. Metode Ijtihad Majlis Tarjih Muhammadiyah, Jakarta: Logos, 1995.

Ismail Muhammad Syah. Filsafat Hukum Islam, Jakarta: Bumi Aksara,1992.

Lily Rasjidi. Hukum Perkawinan dan Perceraian di Malaysia dan Indonesia, Bandung: PT. Remaja Rosdakarya, 1991.

Muhammad Bagir. Fiqib Praktis II: Menurut Al-Qur'an, As-Sunnah dan Pendapat Para Ulama', Bandung: Karisma, 2008.

Muhammad Ra'fat 'Utsman. Fikih Khitbah dan Perkawaninan (Edisi Perempuan), Depok: Fathan Media Prima, 2017.

Muhammad Thahir bin 'Asyur. Maqashid al-Syari'ah al-Islamiyyah, t.tp.: Dar al-Nafa'is, 2001.

M. Muaz Dirjowiyoto. Bagaimana Menghadapi Masalah Lanjut Usia (Nasehat Perkawinan Keluarga), t.tp.: t.p., 1993.

Nasrun Rusli. Konsep Ijtihad al-Syankani Relevansinya bagi Pembaharuan Hukum Islam di Indonesia, Jakarta: Logos Wacana Ilmu, 1999.

Pakih Sati. Panduan Lengkap Perkawaninan: Fiqh Munakahat Terkini, Jogjakarta: Bening, 2011.

Sulaiman Rasjid. Fiqh Islam, Bandung: Sinar Baru Algensindo, t.t. 
Roisul Umam Hamzah: Perkawinan Lansia di Kecamatan Socah.....

Tim Disbintalad. Al-Qur'an dan Terjemahnya, Jakarta: PT Sari Agung,1995.

Wael B. Hallaq. Sejarah Teori Hukum Islam, Pengantar untuk. Usul Fiqih Maz̧hab Sunni, terj. E. Kusnadiningrat dan Abdul haris bin Wahid, Jakarta: PT. Raja Grafindo Persada, 2010)

Zainuddin Ali. Hukum Perdata Islam di Indonesia, Jakarta: Sinar Grafika, 2007.

Zakiyah Darajat. et al. Ilmu Fikih, jilid 3, Jakarta: Depag RI, 1985. 